\title{
The Contextual Causes of Issue and Party Voting in American Presidential Elections
}

\author{
Benjamin Highton
}

Published online: 8 January 2010

(C) The Author(s) 2010. This article is published with open access at Springerlink.com

\begin{abstract}
This paper analyzes the influence of the two most commonly examined causes of presidential vote choice, policy preferences and party identification. The focus is on change across elections in order to assess how the effects of issues and partisanship respond to the larger political context in which voters make their decisions. In contrast to party centric views of politics, I find little direct responsiveness to party issue contrast and substantial influence of candidate issue contrast. Further, I find that leading hypotheses for the "resurgence in partisanship" are not consistent with some important facts suggesting that the explanation remains elusive.
\end{abstract}

Keywords Presidential elections - Voting · Party identification ·

Partisan resurgence $\cdot$ Issues $\cdot$ Policy preferences

Partisanship and policy preferences have long been among the most studied determinants of vote choice in presidential elections. Classic studies like The American Voter (Campbell et al. 1960) found party identification to be of central importance for ballot choice. In contrast seminal rational choice works like $A n$ Economic Theory of Democracy (Downs 1957) placed issues and ideology at the forefront without considering psychological concepts like party identification. Over time scholarly knowledge about the effects of partisanship and issues has grown considerably, and it is now common to find explanations of vote choice that emphasize issues and partisanship (e.g., Miller and Shanks 1996; Adams et al. 2005; Lewis-Beck et al. 2008).

B. Highton $(\square)$

Department of Political Science, University of California, One Shields Avenue, Davis, CA 95616-8682, USA

e-mail: bhighton@ucdavis.edu 
While individual-level models of voting behavior consistently reveal effects of issues and partisanship, variation in these effects across elections has received less attention. This paper's central focus is how the political context determines the magnitude of influence issue preferences and partisanship exert on the choice between presidential candidates. Drawing on a variety of theoretical perspectives, I suggest that this variation may be explained by the behavior of political parties and their candidates. Levels of party mobilization, party polarization, and candidate polarization may all be significant.

Analyzing these relationships is important for several reasons. First, there are a variety of competing explanations regarding why issues and partisanship influence voting behavior that cannot be assessed through cross-sectional analyses of data from a single election. For example, to determine if the effect of party identification is conditioned by the level of elite party polarization (Wattenberg 1998; Bartels 2000) it is necessary to examine multiple elections to provide variation in elite polarization. Second, key questions about the nature of electoral accountability can be addressed. If voters respond to party issue contrast, then the party centric view of politics is strengthened, especially if voters are more responsive to party contrast than to candidate contrast. On the other hand, if party contrast is less important, then the possibility for candidates and their behavior to influence voting is enhanced. In addition, to the extent that voters respond to candidate issue contrast, the amount of issue voting is a short-term factor, subject to change, sometimes, dramatic change, from one election to the next. If voters primarily respond to party issue contrast, then issue voting is better conceived as a long-term force because while party issue contrast may change over time, it is likely to change only incrementally from one election to the next. Related, some models of elections emphasize the importance of party issue reputations, and by implication party issue contrast, as relatively easy heuristics for voters to use in an electoral environment where policy information about candidates is scarce and uncertainty is common (Snyder and Ting 2002, 2003; Woon and Pope 2008). These models are typically applied to low information elections, and if the underlying logic is correct, then party reputations should be much less important in presidential elections where information about the candidates is abundant. Because information about presidential candidates is more plentiful and easier to obtain in comparison to congressional candidates, presidential elections provide a useful context to assess claims about more general propositions about the role of information for electoral behavior. Finally, analyzing how the individual-level effects of partisanship and issues relate to characteristics of the political context contributes to the larger movement toward viewing political behavior as the product of individual characteristics interacting with the environment in which those decisions are made.

The empirical analysis is based on the nine presidential elections from 1972 to 2004. The data primarily come from the American National Election Studies surveys conducted in the midst and immediate aftermath of those campaigns. While the raw materials are individual attitudes and behaviors of voters, the explanatory leverage derives from comparisons across elections. As such, this paper follows in the tradition started by Stokes (1966) in his investigation of "Some Dynamic Elements of Contests for the Presidency" and continued in work like that of Erikson et al. (2002) on the Macropolity and Zaller (2004) on "Floating Voters." 


\section{Policy Voting}

Issues and their influence on the vote have long had a place on the mass behavior research agenda. ${ }^{1}$ As commonly observed, in order for issue preferences to influence ballot choices, the choice presented to voters must provide policy alternatives. If voters are choosing between two alternatives both of which represent identicalreal and perceived-ideological and policy options, then there is no reason the votes of those with liberal preferences to differ from the ballot choices of those with conservative preferences (Berelson et al. 1954; Downs 1957; Campbell et al. 1960; Key 1966). When there is contrast between the alternatives, voters' issue preferences may influence them to choose one over the other, and the larger the ideological and policy divide, the more influential voters' preferences are typically expected to be. ${ }^{2}$

The question addressed in this paper is to what "alternatives" refers. Presidential general elections are contests between candidates from different parties, as most general elections in the United States are. Because parties are ideologically heterogeneous, in any given election the amount of candidate policy contrast and party policy contrast need not be identical. Even in contemporary U.S. politics where the parties have become more internally unified and distinct from each other, neither the Democratic nor Republican parties are ideological monoliths (McCarty et al. 2006). And, nothing in the elaborate and continually revised process of selecting party nominees for president suggests, let alone guarantees, that the eventual nominees will represent the "median" partisans. To be sure, the fact that candidates are chosen from their respective parties might cause the level of candidate contrast to be influenced by the level of party contrast. ${ }^{3}$ But, there is ample room for the correlation to be less than perfect.

Theoretically, voters might respond to parties, candidates, or both. The case for responsiveness to parties begins with the party centric view of political thinking (Campbell et al. 1960; Converse 1964; Green et al. 2002). To the extent that parties are central elements of the voters' belief systems, the implication is that policy preferences will be more influential at separating Democratic and Republican voters when the policy and ideological contrast between the parties is greater. Thus the authors of The American Voter conceived of responsiveness in terms of party contrast. They claimed that an "issue will have no meaningful bearing on partisan choice unless the person can discriminate between the policies of the two parties in the matter" (Campbell et al. 1960, 179, italics added). ${ }^{4}$

\footnotetext{
${ }^{1}$ I use the terms policy preferences and issue preferences interchangeably.

2 This notion follows directly from spatial theories of voting. In addition, the effect of policy preferences may be magnified further in instances of greater contrast due to the behavior of the mass media. If the media pays greater attention to issues in elections where the contrast between choices is greater, then policy preferences may become even more influential for differentiating vote choices than one would expect on the basis of spatial theory alone.

3 I return to this point in the Discussion.

4 Key (1966) provides a similar rationale leading to a focus on responsiveness in terms of party positions. "Standpatters stay by the party even... [when] they agree with the opposition party (Key 1966, p. 150).
} 
There is also an informational rationale for responsiveness to party issue contrast. Snyder and Ting $(2002,2003)$ posit that voters perceive and respond to party ideological and issue locations but not to those of their respective candidates. The logic derives from the proposition that information about party ideological and issue reputations is more plentiful and less uncertain, making it a low cost and useful heuristic. ${ }^{5}$ Along with Woon and Pope (2008), Snyder and Ting apply the model to House elections and find evidence supporting it. Because candidates change from one election to the next while parties are relatively stable, party issue reputations may serve as useful heuristics in presidential elections, too.

Alternatively, while party issue reputations may be easily accessible, in presidential elections, compared to congressional ones, there is much more information made available about the candidates' ideological and issue positions that may serve to reduce voters' uncertainty about them. If voters rely on party issue reputations as a heuristic when candidate issue reputations are difficult to discern, then in presidential elections voters may rely less on party issue reputations and shift their attention and be more responsive to the candidates' positions. In addition, while most descriptive accounts of media coverage of presidential elections find that there is much more emphasis on topics like the horserace and the candidates' personal characteristics, to the extent that there is issue coverage, it tends to be cast in terms of the candidates' positions, not those of their respective parties. These considerations suggest the possibility that in presidential elections voters will be more responsive to candidate policy contrast.

The available empirical evidence is only partially helpful for understanding whether and how voters respond to party and candidate issue contrast. With regard to candidate positions, a variety of studies suggest that candidate contrast is important. In Senate elections, the level of candidate issue contrast has been found to moderate the influence of voters' policy preferences on their choices (e.g., Abramowitz 1981; Wright and Berkman 1986; Highton 2004). At the presidential level, Page and Brody (1972) attribute the lack of any apparent influence of voters' preferences regarding the Vietnam War on presidential voting in the 1968 election to the lack of notable contrast in the positions of Humphrey and Nixon. ${ }^{6}$ Looking across several presidential elections Nie et al. (1976) report larger differences between policy liberals and conservatives in elections with greater contrast in the candidates' issue positions. While the evidence is consistent with the view that the magnitude of candidate issue contrast is important, there are important unanswered questions. None of the studies considers the possibility that party issue contrast may

\footnotetext{
5 This also appears to be the motivating idea behind the view expressed in Voting:
}

[T] he individual voter may not have a great deal of detailed information, but he usually has picked up the crucial general information, as part of his social learning itself... [H]e cannot live in an American community without knowing broadly where the parties stand. He has learned that the Republicans are more conservative and the Democrats more liberal-and he can locate his own sentiments and cast his vote accordingly (Berelson et al. 1954, 321).

${ }^{6}$ Page and Brody (1972) also found that the public perceived McCarthy as more dovish and Reagan as more hawkish and found that in a simulated election "between McCarthy and Reagan, Vietnam preferences had a sizable impact-much greater than in the actual Humphrey-Nixon election" (p. 993). 
be an influential factor and its effects are unexamined. Related, insight into the relative contributions of party and candidate issue contrast is lacking, leaving open the question of whether voters are primarily responsive to parties or to the candidates who run as their standard bearers. ${ }^{7}$

\section{Party Identification and Vote Choice}

Party identification is commonly understood as a relatively stable and enduring psychological attachment to a political party that is part of an individual's social identity (Campbell et al. 1960; Miller and Merrill Shanks 1996; Green et al. 2002). ${ }^{8}$ In elections between candidates of competing parties, one expects partisanship to influence ballot choice as many voters affirm their partisan identities by casting ballots for the candidates who share their party labels. However, just as the larger electoral context may shape the influence of issue preferences on ballot decisions, it may determine how much partisanship matters. Indeed, the relationship between partisanship and presidential voting over time suggests that a purely psychological explanation for why partisanship influences vote choice is inadequate. If the explanation for partisanship as a cause of vote choice depends on internal factors only, then there is no reason to expect the influence of partisanship to vary across a set of elections all of which feature a Democratic candidate running against a Republican one. Yet, research on the "decline" and "revival" of partisanship over the past fifty years suggests that the influence of partisanship on vote choice does vary from one election to the next (Miller 1991; Miller and Merrill Shanks 1996; Wattenberg 1998; Bartels 2000).

There are several aspects of the political context that may be important. One explanation for the influence of partisanship on vote choice views the effect as an instance of mass response to the level of partisanship among elites.

[A] plausible hypothesis is that increasing partisanship in the electorate represents a response at the mass level to increasing partisanship at the elite level. "If parties in government are weakened," Wattenberg argued, "the public will naturally have less of a stimulus to think of themselves politically in partisan terms" (1996, p. 4). But then the converse may also be true: in an era in which parties in government seem increasingly consequential, the public may increasingly come to develop and apply partisan predispositions of

\footnotetext{
7 Nie et al. (1976) is an important study because it compares the influence of policy preferences across elections. But due to changes in survey instrumentation, the indicators of policy preferences also vary across elections, raising the question of whether the observed differences in policy voting are methodological artifacts.

8 While "revisionist" theories that conceive of party identification as responsive to short-term forces have sometimes been advanced, the accumulated empirical evidence is more consistent with the original view. Individual stability in party identification is quite high; it is nearly immune from the influence of short term forces; and, partisanship influences a wide variety of other political attitudes much more so than being influenced by them (Green and Philip 1990, 1994; Schickler and Green 1995; Green et al. 2002; Bartels 2002).
} 
exactly the sort described by the authors of The American Voter (Bartels 2000, p. 44).

Driven by a variety of factors, the parties in government have become increasingly consequential as ideological differences have been on the rise over the past several decades (Rohde 1991; McCarty et al. 2006; Theriault 2008). And the rate picked up considerably in the 1990s. Hetherington (2001) explicitly links this polarization to "resurgent mass partisanship" in a variety of public opinion indicators. The unanswered question addressed here is whether the growing party polarization in government may have caused the influence of partisanship on presidential voting to grow as well.

A second explanation that predicts variation in the influence of party identification on vote choice focuses on the role that party organizations can serve in "activating" and "reinforcing" partisanship. Lazarsfeld et al. (1948) introduced these terms to describe (a) the process by which undecided voters come to "join the fold to which they belong" (activation), and (b) how partisans are kept "in line" with the consequence of reducing defection (reinforcement). While party contact has been extensively analyzed as a cause of turnout (Rosenstone and Hansen 1993) it is important to note that when parties attempt to mobilize voters, they are not merely trying to increase turnout; they are trying to increase votes for their respective candidates. If one election is marked by more party efforts than another, then it is plausible to hypothesize that the influence of partisanship on vote choice will be larger due to greater levels of activation and reinforcement caused by those party efforts.

\section{Research Design}

The nine presidential elections between 1972 and 2004 are the focus of the empirical analysis. Ideally, even more elections would be included, but the necessary individual-level survey data extends back only until 1972. Those data are from the American National Election Studies presidential year surveys. When modeling the determinants of vote choice, only major party voters are included. ${ }^{9}$ The approach I adopt is to estimate separately the individual-level determinants of vote choice in each of the nine elections. To test the issue voting hypotheses I focus on the "total" issue effect in each election-described below-and analyze how it varies with candidate and party issue contrast. I test the hypotheses about why partisanship influences vote choice by comparing patterns of change in the effect of party identification across elections to those for party elite polarization and party voter contacting.

\footnotetext{
9 In most years this decision is necessarily inconsequential because minor party and independent presidential candidates receive hardly any votes. The 1992 election, where Ross Perot received nearly $20 \%$ of the vote, is potentially more problematic, but as will be apparent, none of the hypothesis tests depends on the results for 1992. Moreover, both Bartels (2000), which analyzes presidential elections over time, and Miller and Shanks (1996), which offers a book length treatment of the 1992 election, exclude Perot voters when analyzing the determinants of vote choice in 1992.
} 
The key measures in the individual-level vote choice models are issue attitudes and partisanship. ${ }^{10}$ To measure voters' issue attitudes, I use five questions asked In identical fashion in each of the nine surveys that cover general ideological, economic, racial, and cultural divides in America. The first is a question about ideology that asks respondents to place themselves on a scale ranging from very liberal to very conservative (libcon). ${ }^{11}$ The second scale is about whether the government should guarantee people jobs or whether the government should let people get ahead on their own (jobs). The third asks whether the government should make every effort to improve the condition of blacks and minorities or whether they should help themselves (black aid). The fourth runs from the belief that women and men should have an equal role in running business, industry, and government to the view that a women's place is in the home (women's role). The last issue question gives respondents four options regarding the conditions under which a woman should be allowed to have an abortion (abortion). ${ }^{12}$ I coded responses to all five questions to range from 0 (most liberal response) to 1 (most conservative response). ${ }^{13}$

The measure of the total issue effect in a given election is the sum of the estimated effects for each of the five policy preference items. The motivating idea is that each of the items is an indicator of underlying policy preferences and that there is likely overlap across indicators, which makes it less meaningful to interpret the apparent influence of any single measure rather than interpreting the joint influence of them all (Achen 1985; Ansolabehere et al. 2008). By taking the sum of the five estimates, I produce a quantity that estimates how different the vote choice of an individual who chooses the most liberal option on all five questions would be from an individual who chooses the most conservative option on all five questions. ${ }^{14}$ Comparing this quantity across elections and observing how it correlates with

\footnotetext{
${ }^{10}$ Consistent with other studies of presidential voting, the individual vote choice models also include a set of demographic control variables: family income, education, region (the South, defined as the 11 former Confederate states), union membership, sex, race, religion (Catholic, mainline Protestant, evangelical Protestant, and Jewish), and frequency of church/synagogue attendance. By estimating separate models for each presidential election, the effects of all of these variables are allowed to vary across elections.

${ }^{11}$ In the 2000 survey some respondents were asked the usual ideology question and others were randomly selected to be asked an experimental version of the questions. The latter respondents are excluded from the analysis.

12 The wording of the abortion question modestly changed in 1980. Fortunately both the old and new versions were included in the 1980 ANES survey. The empirical results are nearly identical regardless of which version is used in 1980.

${ }^{13}$ Respondents who did not choose a position/location on the items were assigned the mean value for the item in the designated year. Among major party voters, fully $88 \%$ of respondents chose locations for four or five of the items and $96 \%$ located themselves on at least three.

${ }^{14}$ This approach is similar to creating a measure of issue attitudes based on the indicators and using that measure as an independent variable in the vote choice model (Bartels 2006). The primary difference is that including the separate indicators and then summing their effects allows the effects of the indicators to vary while the former method entails the implicit assumption that the effects are equal across indicators. That said, the findings regarding the responsiveness of voters to candidate issue contrast and party issue contrast are nearly identical when an issue scale is used rather than taking the sum of the individual issue effects.
} 
candidate and party contrast makes it possible to test the hypotheses regarding the causes of issue voting.

To measure party identification, I rely on the standard ANES questions that ask respondents whether they consider themselves Democrats or Republicans, whether those feelings are strong, and if respondents do not consider themselves partisans, whether they feel closer to one of the two parties. In light of previous research showing that "weak" partisans and "leaners" are quite similar on a host of political dimensions and distinguished from "strong" partisans (Keith et al. 1992), I use a five category measure that distinguishes strong Democrats, weak and leaning Democrats, weak and leaning Republicans, strong Republicans, and others, who are placed at the midpoint of the scale. ${ }^{15}$

There are four measures of the political context used in the analysis. To measure candidate and party issue contrast, I rely on NES questions that ask respondents to place the parties and candidates on four scales that match four of the policy questions used in the vote choice models, ideology, government guaranteed jobs, federal aid to blacks, and the proper social role for women. ${ }^{16}$ To provide an election-level measure of candidate issue contrast, I compute the average locations for each candidate on each indicator. The average difference across the four items serves as the election-level measure of candidate contrast, and is as described more fully in the Appendix. I do the same for party contrast. To facilitate interpretation, I rescale each to range from the lowest observed value for the nine elections (0) to the highest (1). The results are displayed in Fig. 1. The candidates were least polarized in 1976 (by a large margin) and most polarized in 2004 (barely more than in 1996). The parties were least polarized in 1972 and most polarized in $2004 .{ }^{17}$ Importantly, there is far from a perfect association between the two types of issue contrast- the correlation is .51 - which means empirical tests of the responsiveness hypotheses are possible.

The other two contextual measures are used to test the partisanship hypotheses. Wattenberg (1998) and Bartels (2000) identify party polarization in government as a cause of the influence of partisanship on voting behavior in the mass public. One way scholars commonly measure party polarization in government, or elite party polarization, is with the difference in the average ideological location of Democratic and Republican House members using McCarty et al.'s (2006) first dimension DW-

\footnotetext{
15 Two other possibilities are a three point scale based on the initial question of whether one considers oneself a Democrat, Republican or something else and a seven point scale that differentiates strong, weak, and leaning partisans of each party from pure independents. Empirically, the choice makes little difference for the substantive results.

16 The NES surveys do not ask respondents to place the candidates and parties on abortion policy, the fifth indicator of policy preferences I use, but ideological placements are probably influenced by them, especially in later years as abortion became a more salient political issue. And, because they tap the cultural dimension, placements regarding the proper role for women are likely correlated with placements regarding abortion.

${ }^{17}$ Note the importance of the 1972 election. It provides excellent leverage because while it is the election with the least party issue polarization, it is near the top with regard to candidate issue polarization. To the extent that voters are responsive to candidate issue contrast, 1972 would be marked by a higher level of policy voting and to the extent that party contrast matters, 1972 should evince quite low relative levels of policy voting.
} 


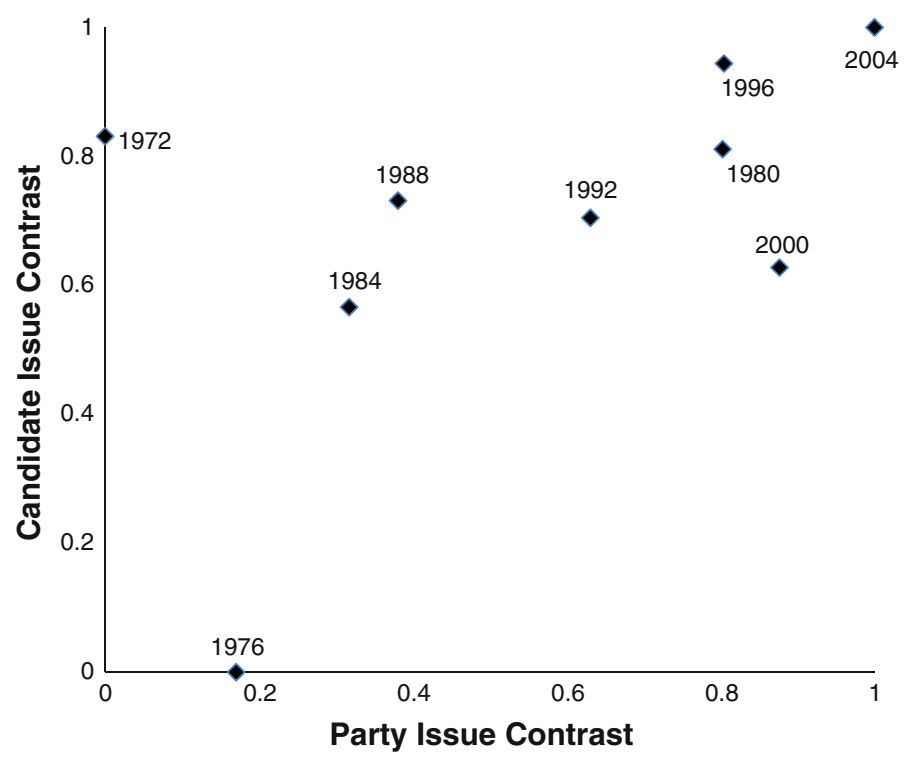

Fig. 1 Presidential candidate issue contrast and party issue contrast, 1972-2004

NOMINATE scores. For individual members these scores typically range from -1 (the most liberal) to +1 (the most conservative). Using this measure, polarization increased from .55 in 1972 to .88 in 2004. The other hypothesized cause of fluctuations in the effect of partisanship on presidential voting is party mobilization. To measure the level of mobilization I rely on the NES question routinely posed to respondents that asks whether they have been contacted by political parties during the campaign. Like the trend for party polarization in government, more recent elections are marked by higher levels of party mobilization.

\section{Results}

For each presidential election, I estimated a probit model of vote choice. ${ }^{18}$ To test the policy voting hypotheses, it is necessary to obtain estimates of the total influence of issue preferences in each election. To do this, I begin with the estimated effects of each of the five policy indicators in each election: libcon, jobs, black aid, abortion, and women's role. With all the variables coded on $0 / 1$ scale, the sum of the five coefficients is the probit estimate of the effect of providing the most liberal response to each item in comparison to providing the most conservative response. The key question is how this quantity varies with the levels of candidate issue contrast and party issue contrast. Table 1 provides the raw material for the answer. For each election, the table reports the total issue effect along with the corresponding levels

\footnotetext{
18 The parameter estimates, standard errors, fit statistics, and numbers of observations are reported in the Appendix.
} 
Table 1 Candidate issue contrast, party issue contrast, and the level of issue voting, 1972-2004

\begin{tabular}{llll}
\hline Election year & Candidate contrast & Party contrast & Total issue effect \\
\hline 1972 & .83 & 0 & 2.98 \\
1976 & 0 & .17 & 2.15 \\
1980 & .81 & .80 & 2.68 \\
1984 & .57 & .32 & 2.98 \\
1988 & .73 & .38 & 2.60 \\
1992 & .70 & .63 & 3.10 \\
1996 & .94 & .80 & 4.04 \\
2000 & .63 & .88 & 2.67 \\
2004 & 1 & 1 & 3.98 \\
\hline
\end{tabular}

Notes: Candidate issue contrast and party issue contrast are described in detail in the main text and the Appendix. Each is scaled to range from 0 (the lowest observed value) to 1 (the highest observed value). The "total issue effect" for each year is based on the probit models of presidential vote reported in Appendix Table 4. The total issue effect is the sum of the estimated effects of the five policy preference indicators

of candidate and party contrast. Two elections stand out as having especially high levels of issue voting, those of 1996 and 2004. The lowest level of policy voting was in the 1976 election.

To assess how the levels of policy voting relate to the levels of candidate and party contrast. Table 2 reports the results of a series of OLS regressions where the total level of policy voting is regressed on the levels of candidate and party issue contrast. The first row of estimates is from a regression including all nine presidential elections between 1972 and 2004. With candidate and party contrast coded to range from their lowest (0) to their highest (1) observed levels, the entries for the unstandardized coefficients indicate how much of an increase in policy voting one would expect in an election with maximum observed contrast compared to one with minimum observed contrast for the respective measures. ${ }^{19}$

Policy voting appears more responsive to candidate issue contrast than party issue contrast. The estimated effect of party contrast is $.35(p=.54)$ while the estimated effect of candidate contrast is four times larger $1.41(p=.07)$. Similar relative effects are evident in the standardized coefficients (.19 for party contrast versus .66 for candidate contrast). While the effect of candidate contrast is large relative to the effect of party contrast, it also appears large relative to the baseline level predicted when candidate and party divergence are at their observed minimums. In this instance, the predicted level of issue voting is 1.86 . The coefficient of 1.41 for candidate divergence suggests that the level of policy voting would be predicted to almost double to $3.27(1.86+1.41)$ in an election with the maximum observed level of candidate contrast.

With just nine observations, it is possible that the results regarding the effects of candidate and party contrast on the level of issue voting are driven by a single

\footnotetext{
19 The constant indicates the expected level of policy voting in an election where contrast is at its minimum observed levels for both.
} 
Table 2 Responsiveness of policy voting to candidate and party issue contrast

\begin{tabular}{|c|c|c|c|c|c|c|}
\hline \multicolumn{7}{|c|}{ Dependent variable $=$ total issue effect } \\
\hline \multirow{2}{*}{$\begin{array}{l}\text { Election year } \\
\text { excluded }\end{array}$} & \multicolumn{3}{|c|}{ Unstandardized estimates } & \multicolumn{3}{|c|}{ Standardized estimates } \\
\hline & Constant & $\begin{array}{l}\text { Candidate } \\
\text { contrast }\end{array}$ & $\begin{array}{l}\text { Party } \\
\text { contrast }\end{array}$ & $\begin{array}{l}\text { Candidate } \\
\text { contrast }\end{array}$ & $\begin{array}{l}\text { Party } \\
\text { contrast }\end{array}$ & $\begin{array}{l}\text { Adjusted } \\
R^{2}\end{array}$ \\
\hline None $(n=9)$ & $1.86(.41)$ & $1.41(.64)$ & $.35(.54)$ & .66 & .19 & .47 \\
\hline 1972 & $1.87(.46)$ & $1.52(.98)$ & $.21(1.01)$ & .70 & .09 & .45 \\
\hline 1976 & $.91(.88)$ & $2.63(1.19)$ & $.28(.52)$ & .69 & .17 & .41 \\
\hline 1980 & $1.83(.37)$ & $1.43(.57)$ & $.52(.49)$ & .67 & .29 & .62 \\
\hline 1984 & $1.79(.47)$ & $1.42(.68)$ & $.40(.59)$ & .66 & .21 & .47 \\
\hline 1988 & $1.91(.42)$ & $1.52(.65)$ & $.21(.55)$ & .74 & .12 & .51 \\
\hline 1992 & $1.85(.46)$ & $1.41(.70)$ & $.34(.59)$ & .66 & .19 & .44 \\
\hline 1996 & $1.97(.38)$ & $1.20(.58)$ & $.25(.48)$ & .67 & .17 & .42 \\
\hline 2000 & $1.91(.42)$ & $1.19(.68)$ & $.62(.61)$ & .57 & .33 & .51 \\
\hline 2004 & $2.00(.44)$ & $1.28(.65)$ & $.14(.57)$ & .67 & .08 & .31 \\
\hline
\end{tabular}

Notes: Candidate and party issue contrast are scaled to range from 0 (lowest observed value) to 1 (highest observed value). When no election years are excluded $n=9$ (first row). Total issue effects are based on the results reported in Table 1 and Appendix Table 4. Standard errors are in parentheses

outlying case. To investigate this possibility, I reestimated the model nine times, each time excluding one of the nine election years. The results are also displayed in Table 2 and are reassuring. The influence of any single election does not drive the finding that issue voting is substantially more responsive to candidate issue contrast than party issue contrast. Across the nine replications, the effect of candidate contrast ranges from 1.19 to 2.63 (the standardized effects range from .57 to .74) while the effect of party contrast ranges from .14 to .62 (the standardized effects range from .08 to .33 ).

Turning to the effects of party identification, if elite party polarization and party voter contacting enhance the influence of individual partisanship on vote choice, then the over time trends should move together. Table 3 shows the values of for all three variables for each of the nine elections. The first set of entries reports the values of the variables after smoothing the year-to-year values to diminish the idiosyncratic effects (including sampling variability) of individual elections that can obscure longer term trends. ${ }^{20}$ (The second set of estimates reports the actual values.) Consistent with previous research, the effect of partisanship and the levels of elite party polarization in government and party contacting have all increased over time. However, the patterns of increase raise doubts about whether the influence of partisanship depends on elite polarization or party contacting. From 1972 to 2004, the estimated effect of partisanship on presidential voting increased .85 , from 2.49 to 3.34. Significantly, virtually all of the increase occurred in the first half of the

\footnotetext{
${ }^{20}$ The smoothing technique is locally weighted regression (lowess).
} 
Table 3 Partisanship effects on presidential vote choice and levels of elite party polarization and party contacting

\begin{tabular}{|c|c|c|c|c|c|c|}
\hline \multirow{2}{*}{$\begin{array}{l}\text { Election } \\
\text { year }\end{array}$} & \multicolumn{3}{|c|}{ Smoothed estimates } & \multicolumn{3}{|c|}{ Unsmoothed estimates } \\
\hline & $\begin{array}{l}\text { Effect } \\
\text { of PID }\end{array}$ & $\begin{array}{l}\text { Elite } \\
\text { polarization }\end{array}$ & $\begin{array}{l}\text { Party contact } \\
\text { (proportion) }\end{array}$ & $\begin{array}{l}\text { Effect } \\
\text { of PID }\end{array}$ & $\begin{array}{l}\text { Elite } \\
\text { polarization }\end{array}$ & $\begin{array}{l}\text { Party contact } \\
\text { (proportion) }\end{array}$ \\
\hline 1972 & 2.49 & .55 & .36 & 2.45 & .55 & .35 \\
\hline 1976 & 2.68 & .56 & .33 & 2.76 & .55 & .35 \\
\hline 1980 & 2.90 & .58 & .31 & 2.77 & .57 & .28 \\
\hline 1984 & 3.09 & .61 & .29 & 3.20 & .62 & .28 \\
\hline 1988 & 3.25 & .65 & .28 & 3.32 & .65 & .30 \\
\hline 1992 & 3.34 & .70 & .31 & 3.40 & .67 & .25 \\
\hline 1996 & 3.39 & .76 & .37 & 3.26 & .79 & .33 \\
\hline 2000 & 3.38 & .83 & .44 & 3.61 & .83 & .48 \\
\hline 2004 & 3.34 & .88 & .53 & 3.26 & .88 & .52 \\
\hline \multicolumn{7}{|l|}{ Change } \\
\hline$(1972-1988)$ & .76 & .10 & -.08 & .87 & .10 & -.05 \\
\hline \multicolumn{7}{|l|}{ Change } \\
\hline (1988-2004) & .09 & .23 & .25 & -.06 & .23 & .22 \\
\hline
\end{tabular}

Notes: For each election year, a probit model of presidential vote was estimated with party identification, five policy preference indicators, and a set of demographic characteristics as independent variables. The entries for "effect of PID" report the probit estimates (see Appendix Table 4). Level of elite party polarization is the difference in average DW-NOMINATE scores between Democratic and Republican members of Congress. Proportion contacted is the proportion of voting partisans that report being contacted by one of the parties. See main text for more extensive descriptions. Smoothed estimates are based on lowess regressions

period, .76 from 1972 to 1988 , compared to just .09 from 1988 to 2004. In contrast, it was in the second half of the period that party polarization and contacting increased the most. About two-thirds of the increase in party polarization occurred in the second half of the period compared to the first (.23 vs .10) while party contacting declined .08 in the first half of the period before increasing .25 in the second. The same patterns are evident using the second set of entries, based on the actual, unsmoothed, estimates. If the influence of partisanship on presidential voting depends in a significant way on either party polarization or party contacting, then the effect of partisanship would have increased more substantially in the second half of the period rather than the first. ${ }^{21}$ Thus while the results reported here are consistent with the claim that there has been a resurgence of partisanship in presidential voting, they suggest that new explanations for the increase may be necessary, a point I return to below.

\footnotetext{
${ }^{21}$ Even with a model that excludes issue attitudes, the apparent increase in the influence of partisanship on presidential voting is concentrated in the 1970s and 1980s rather than the 1990s and 2000s when elite polarization contacting were increased more substantially.
} 


\section{Discussion and Conclusion}

From one election to the next, the political context in which voters cast their ballots may change in a variety of ways. This paper has been concerned with the implications for the determinants of voting behavior. The first broad theoretical concern of the paper was with the nature of issue voting and whether voters respond to issue contrast between the parties and their respective candidates. Contrary to the party centric view espoused in The American Voter (Campbell et al. 1960), candidate contrast appears to drive the magnitude of issue voting with little direct responsiveness to party contrast evident in the results. Whether the parties were more or less divergent on policy issues was barely related to the effect of issue preferences on presidential vote choice. This result is consistent with the rationale offered by Snyder and Ting $(2002,2003)$ and Woon and Pope (2008) for why party reputations matter in low information elections. These studies claim that party issue reputations are easy heuristics to rely on when candidate locations are hard to discern as they typically are in low information elections. Had evidence of responsiveness to party issue contrast been evident in presidential elections (the epitome of "high information" elections), then the claim that voters rely on party reputations in low information elections because information about candidates is scarce and uncertain would be less convincing.

The finding that voters are not especially responsive to party issue contrast does not imply that party positions are insignificant factors in presidential elections. Candidates are selected by their respective parties and therefore to explain the level of candidate issue contrast one would naturally turn to the level of party issue contrast. When the parties are more internally unified and more differentiated from each other, it is reasonable to expect a higher level of candidate contrast than when party differences are muted. The association between party contrast and candidate contrast (recall Fig. 1) is more likely due to the causal effect of the former on the latter than vice versa. Thus, party contrast may not exert much of a direct effect on the structure of presidential vote choice, but its indirect effect is likely substantial. That said, there is far from an iron law relationship between candidate and party contrast as the 1972 presidential election makes perfectly clear. Party contrast was its lowest level of the nine election analyzed in this paper, yet candidate contrast was much higher.

The second, related, theoretical concern of the paper was with explaining why partisanship influences vote choice. In this regard, the paper's contribution derives from ruling out two plausible hypotheses. Neither the changes in elite party polarization nor party contacting match the observation that the growth in the effect of party identification on presidential voting was concentrated in the 1970s and 1980s, not the 1990s and 2000s when elite party polarization and party contacting were increasing more substantially. The implication is that future research should focus on the 1972-1988 period to identify other potential causes of "resurgent of partisanship." One possible avenue would be to consider the images of the parties in relation to the social groups associated with them (Green et al. 2002). If the postCivil Rights and early countercultural periods left the party images more ambiguous than they had been (and would become), then one would expect the influence of 
partisanship on voting behavior (and other forms of political behavior and public opinion) to be weakened. If the period from 1972 to 1988 marks the time when the party images clarified again, then it may explain the growing influence of partisanship on presidential voting.

The view that elite party polarization is not the force behind the increasing influence of partisanship on presidential voting is at odds with leading accounts of the resurgence of partisanship in the mass public (Wattenberg 1998; Bartels 2000; Hetherington 2001). These studies identify growing levels of elite party polarization in government as the cause of the growing importance of partisanship in the mass public. Of the three, only Hetherington (2001) attempts to test directly the hypothesis and reports strong results from regressing a variety of partisanship indicators on the level of elite party polarization. But, these findings may be methodological artifacts. The tests focus on the 1984-1996 period when the indicators of partisanship and elite polarization were all trending upward. ${ }^{22}$ As a result, even if there was no causal effect of polarization on partisanship, an "effect" would have been found because of the common upward trend. ${ }^{23}$ In a case like this it is necessary to compare changes in the amount of change rather than changes in levels. $^{24}$

Finally, a larger implication of this study relates to Key's (1966) metaphor of the electoral system as an "echo chamber." While he emphasized the interrelationships between voters, candidates, and parties, it has taken decades for political scientists to invest substantial energy into the elaboration of the nature of those links. By analyzing how the effects of party identification and issue preferences-two of the most commonly identified influences on presidential voting - depend on the larger political context, this paper contributes to that effort. Although questions remain to be answered, the conclusion that the answers will require continued attention to the connections between voters and the environment in which they make their decisions rests on firm footing.

Acknowledgment I appreciate comments and criticism from Ryan Claassen, George Rabinowitz, John Sides, Walt Stone, and the editors and reviewers at Political Behavior.

Open Access This article is distributed under the terms of the Creative Commons Attribution Noncommercial License which permits any noncommercial use, distribution, and reproduction in any medium, provided the original author(s) and source are credited.

\footnotetext{
22 See Hetherington (2001), Table 1.

23 Any independent variable with an upward trend, even one with no plausible causal relationship to partisanship — say, average global temperature-would appear to "cause" partisanship in this situation.

24 In the present study, the correlation between the effect of partisanship on presidential voting and elite party polarization is .83 , reflecting the fact that both were increasing during the entire period under analysis. But the correlation between the change in the effect of partisanship (between the current and previous election) and the change in the level of elite polarization is -.85 , reflecting the fact that when the effect of party identification changed most (early in the period) the level of elite polarization changed least and vice versa (later in the period).
} 


\section{Appendix}

\section{Measuring Candidate and Party Policy Contrast}

To construct a composite election-level measure of candidate policy contrast, I rely on four sets of questions. ANES respondents have routinely been asked to place presidential candidates on the libcon, black aid, jobs, and women's role scales. At the individual level, questions like these are subject to a variety of biases. For example, people who like a candidate for other reasons are likely to place that candidate closer to their preferred location while placing candidates they dislike further away. A common approach to address problems like this is to compute the average of the individual responses, which has the effect of reducing substantially the influence of individual biases because they tend to cancel out in the aggregate (e.g., Rabinowitz and Macdonald 1989; Zaller 2004). These aggregate indicators of "candidate reputations" have been demonstrated to be closely related to actual locations as measured by voting records and candidate surveys (Erikson 1990; Burden et al. 2000). For each item I compute the mean and then the difference between the candidates to produce indicators of candidate divergence. All four indicators are available for every election except 1984 (women's role was not asked) and 1992 (black aid and women's role were not asked). For these missing indicators, I imputed values based on the observed values of the other variables and their interrelationships in other years. The overall measure of candidate divergence in an election is the average of these four differences in each election year. As Appendix Fig. 2 shows, these indicators tend to move together. (In this figure each indicator is standardized to mean $=0$ and standard deviation $=1$.) The most notable exception is 1980 where libcon moves toward less divergence (compared to 1976) while the other indicators (especially black aid and women's role) move toward greater divergence. Fortunately, as shown in Table 2, the issue voting responsiveness results do not significantly depend on whether the 1980 election is included or excluded from the analysis.

The composite measure of election-level party policy contrast is constructed in a similar fashion. However, there are more imputations for the indicators of party divergence because the party location questions were not asked in some years for jobs (1996), black aid (1992, 1996) and women's role (1984, 1992, 1996, 2000). This is less problematic than it would be for candidate contrast because there is less election-to-election variation in party locations. And, there is another indicator of party contrast available for the imputations, the level of party polarization in Congress (Fig. 1). Appendix Fig. 3 shows how the four indicators move together. Like the indicators of candidate divergence, 1980 appears to stand out, but as noted above, this has little effect on the substantive findings reported in the paper.

\section{Election-by-Election Individual Vote Choice Models}

As described in the main text, for each of the nine presidential elections from 1972 to 2004 , I estimated a vote choice model that included the five indicators of issue attitudes, party identification, and a battery of demographic variables. By estimating 


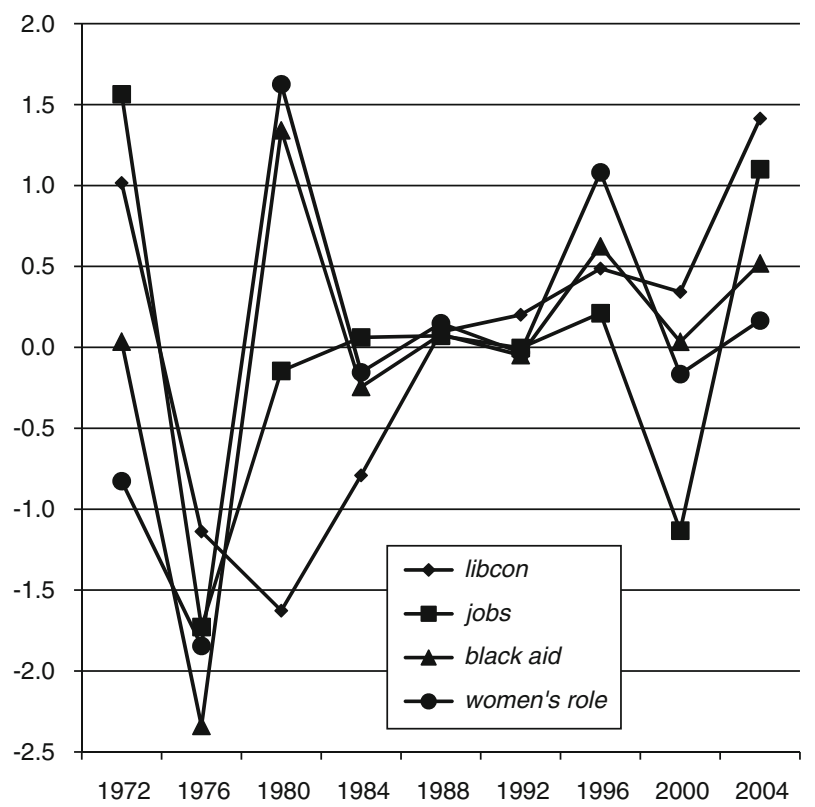

Fig. 2 Indicators of candidate policy contrast

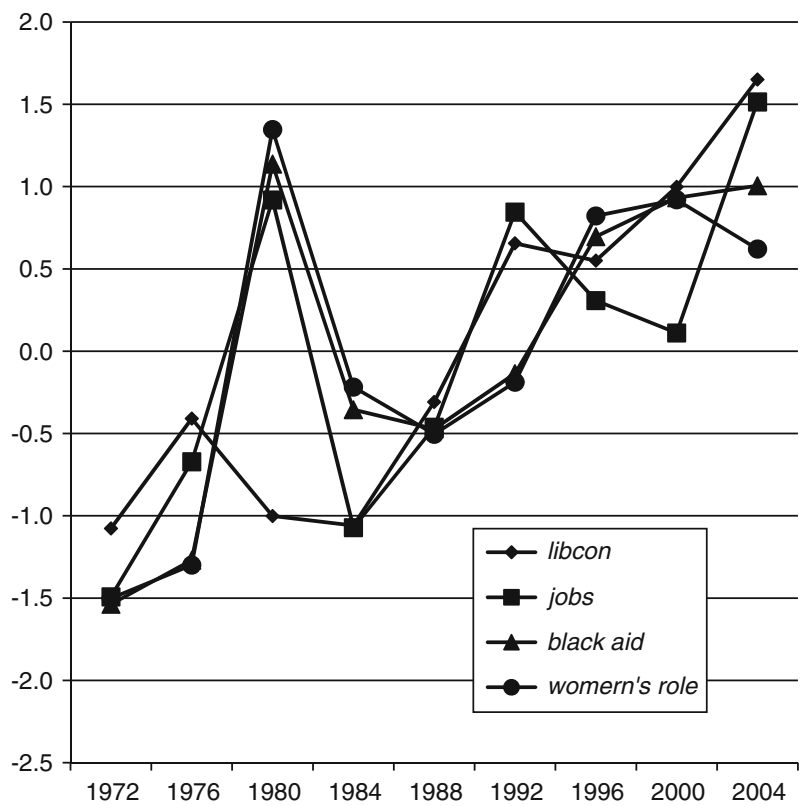

Fig. 3 Indicators of party policy contrast 


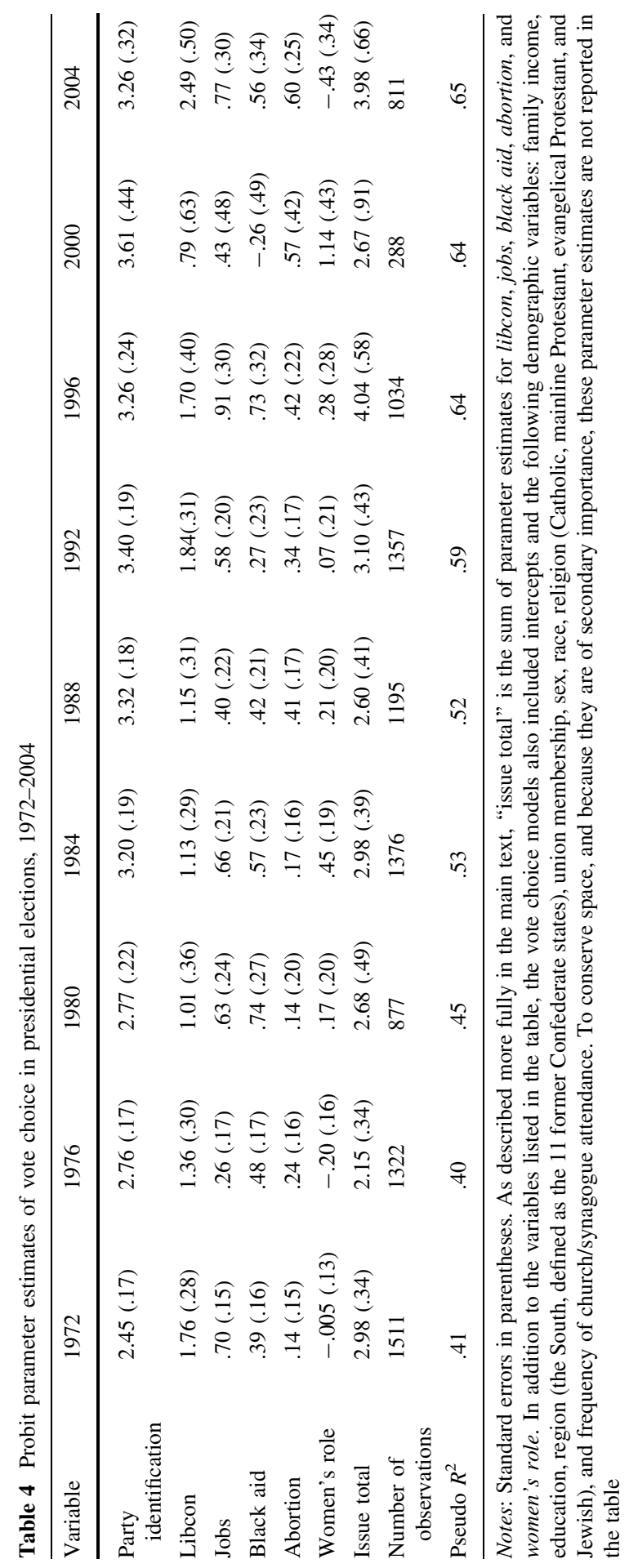


separate models for each election, there is no constraint placed on how (if at all) the effects vary from one election to the next. The parameter estimates, standard errors, model fit statistics, and numbers of observations are reported in Appendix Table 4.

\section{References}

Abramowitz, A. I. (1981). Choices and echoes in the 1978 senate elections: A research note. American Journal of Political Science, 25, 112-118.

Achen, C. H. (1985). Proxy variables and incorrect signs on regression coefficients. Political Methodology, 11, 299-316.

Adams, J. F., Merrill, S., \& Grofman, B. (2005). A unified theory of party competition: A cross-national analysis integrating spatial and behavioral factors. New York: Cambridge University Press.

Ansolabehere, S., Rodden, J., \& Snyder, J. M, Jr. (2008). The strength of issues: Using multiple measures to gauge preference stability, ideological constraint, and issue voting. American Political Science Review, 102(2/May), 215-232.

Bartels, L. M. (2000). Partisanship and voting behavior, 1952-1996. American Journal of Political Science, 44(1), 35-50.

Bartels, L. M. (2002). Beyond the running tally: Partisan bias in political perceptions. Political Behavior, 24(2), 117-150.

Bartels, L. M. (2006). Priming and persuasion in presidential campaigns. In H. E. Brady \& R. Johnston (Eds.), Capturing campaign effects. Ann Arbor, MI: University of Michigan Press.

Berelson, B. R., Lazarsfeld, P. F., \& McPhee, W. N. (1954). Voting: A study of opinion formation in a presidential campaign. Chicago: University of Chicago Press.

Brewer, M. D., \& Stonecash, J. M. (2009). Dynamics of American political parties. New York: Cambridge University Press.

Burden, B. C., Caldeira, G. A., \& Groseclose, T. (2000). Measuring the ideologies of U.S. senators: The song remains the same. Legislative Studies Quarterly, 25(2/May), 237-258.

Campbell, A., Converse, P. E., Miller, W. E., \& Stokes, D. E. (1960). The American voter. New York: John Wiley \& Sons.

Converse, P. E. (1964). The nature of belief systems in mass publics. In D. E. Apter (Ed.), Discontent ideology. New York, NY: Free Press.

Downs, A. (1957). An economic theory of democracy. New York: Harper \& Row.

Erikson, R. S. (1990). Roll calls, reputations, and representation in the U.S. senate. Legislative Studies Quarterly, 15(4/November), 623-642.

Erikson, R. S., MacKuen, M. B., \& Stimson, J. A. (2002). The macro policy. New York: Cambridge University Press.

Green, D. P., \& Palmquist, B. (1990). Of artifacts and partisan instability. American Journal of Political Science, 34(3), 872-902.

Green, D. P., \& Palmquist, B. (1994). How stable is party identification? Political Behavior, 16(4), 437-466.

Green, D. P., Palmquist, B., \& Schickler, E. (2002). Partisan hearts and minds. New Haven, CT: Yale University Press.

Hetherington, M. J. (2001). Resurgent mass partisanship: The role of elite polarization. American Political Science Review, 95(3/September), 619-631.

Highton, B. (2004). Policy voting in senate elections: The case of abortion. Political Behavior, 26(2/June), $181-200$.

Keith, B. E., Magleby, D. B., Nelson, C. J., Orr, E., Westlye, M. C., \& Wolfinger, R. E. (1992). The myth of the independent voter. Berkeley: University of California Press.

Key, V. O. (1966). The responsible electorate: Rationality in presidential voting, 1936-1960. Cambridge, MA: Harvard University Press.

Lazarsfeld, P. F., Berelson, B., \& Gaudet, H. (1948). The people's choice: How the voter makes up his mind in a presidential campaign. New York: Columbia University Press.

Lewis-Beck, M. S., Norpoth, H., Jacoby, W., \& Weisberg, H. F. (2008). The American voter revisited. Ann Arbor, MI: University of Michigan Press. 
McCarty, N., Poole, K. T., \& Rosenthal, H. (2006). Polarized America: The dance of ideology and unequal riches. Cambridge: MIT Press.

Miller, W. E. (1991). Party identification, realignment, and party voting: Back to the basics. American Political Science Review, 85, 557-568.

Miller, W. E., \& Shanks, J. M. (1996). The new American voter. Cambridge: Harvard University Press.

Nie, N. H., Verba, S., \& Petrocik, J. R. (1976). The changing American voter. Cambridge, MA: Harvard University Press.

Page, B. I., \& Brody, R. A. (1972). Policy voting and the electoral process: The Vietnam War issue. American Political Science Review, 66(September), 979-995.

Rabinowitz, G., \& Macdonald, S. E. (1989). A directional theory of issue voting. American Political Science Review, 83(March), 93-121.

Rohde, D. (1991). Parties and leaders in the postreform house. Chicago, IL: University of Chicago Press.

Rosenstone, S. J., \& Hansen, J. M. (1993). Mobilization, participation, and democracy in America. New York, NY: Macmillan.

Schickler, E., \& Green, D. (1995). Issue preferences and the dynamics of party identification: A methodological critique. Political Analysis, 5, 151-179.

Snyder, J., \& Ting, M. (2002). An informational rationale for political parties. American Journal of Political Science, 46(1), 90-110.

Snyder, J., \& Ting, M. (2003). Roll calls, party labels, and elections. Political Analysis, 11(4), 419-444.

Stokes, D. E. (1966). Some dynamic elements of contests for the presidency. American Political Science Review, 60(1), 19-28.

Theriault, S. M. (2008). Party polarization in congress. New York, NY: Cambridge University Press.

Wattenberg, M. P. (1998). The decline of American parties, 1952-1996. Cambridge: Harvard University Press.

Woon, J., \& Pope, J. (2008). Made in congress? Testing the electoral implications of party ideological brand names. Journal of Politics, 70(July), 823-836.

Wright, G. C., \& Berkman, M. B. (1986). Candidates and policy in United States senate elections. American Political Science Review, 80, 567-588.

Zaller, J. (2004). Floating voters in U.S. presidential elections, 1948-2000. In W. E. Saris \& P. M. Sniderman (Eds.), Studies in public opinion: Attitudes, nonattitudes, measurement error, change. Princeton: Princeton University Press. 